ISSN : $2302-1590$

E-ISSN: $2460-190 \mathrm{X}$

\title{
ECONOMICA
}

Journal of Economic and Economic Education Vol.5 No.1 (47 - 57)

\section{ANALISIS PENDAPATAN NELAYAN PEMILIK PAYANG DI KECAMATAN KOTO TANGAH KOTA PADANG}

\author{
Lovelly Dwinda Dahen \\ Dosen Program Studi Pendidikan Ekonomi STKIP PGRI Sumbar \\ Jl. Gunung Pangilun No.1, Padang Sumatera Barat \\ Email:lovendalovelly@yahoo.com \\ submited: 2016.09.16 reviewed: 2016.11.02 accepted: 2016.12.17 \\ http://dx.doi.org/10.22202/economica.2016.v5.i1.891
}

\begin{abstract}
This study aims to analyze (1) the influence of capital income seine fishermen in the district of Koto Tangah Padang. (2) the effect on revenue Mileage fishing seine fishermen in the district of Koto Tangah Padang. (3) the effect of experience on the income of fishermen in the district payang Tangah Koto Padang. (4) the effect of the capital, mileage and experience to sail together to the income of fishermen in the district payang Tangah Koto Padang. This type of research is descriptive associative. The population in this study is the owner seine fishermen in the district of Koto Tangah Padang. The sampling technique is purposive sampling with the number of 111 fishermen payang owner. Data were collected through questionnaires open. This study uses linear regression analysis tool. Our research found that: 1) Capital partially significant effect on the income of fishermen in the district Payang owner Tangah Koto Padang. 2) Working Hours partially significant effect on the income of fishermen in the district Payang owner Tangah Koto Padang. 3) Experience partially significant effect on the income of fishermen in the district Payang owner Tangah Koto Padang. 4) capital, hours of work and simultaneously experience a significant effect on the income of fishermen in the district Payang owner Tangah Koto Padang. Based on these results obtained by the variable capital is the most dominant variables contribute to fishermen's income earned from fishing activities.
\end{abstract}

\begin{abstract}
Abstrak
Penelitian ini bertujuan untuk menganalisis (1) pengaruh modal terhadap pendapatan nelayan payang di kecamatan Koto Tangah kota Padang. (2) pengaruh jam kerja terhadap pendapatan nelayan payang di kecamatan Koto Tangah kota Padang. (3) pengaruh pengalaman terhadap pendapatan nelayan payang di kecamatan Koto Tangah kota Padang. (4) pengaruh modal, jam kerja dan pengalaman secara bersama-sama terhadap pendapatan nelayan payang di kecamatan Koto Tangah kota Padang. Jenis penelitian ini adalah deskriptif asosiatif. Populasi dalam penelitian ini adalah nelayan pemilik payang di kecamatan Koto Tangah kota Padang. Teknik pengambilan sampel adalah Purposive Sampling dengan jumlah sampel 111 orang nelayan pemilik payang. Data dikumpulkan melalui kuesioner terbuka. Penelitian ini menggunakan alat analisis Regresi Linear Berganda. Hasil penelitian ini menemukan bahwa: 1) Modal secara parsial berpengaruh signifikan terhadap pendapatan nelayan pemilik Payang di Kecamatan Koto Tangah kota Padang. 2) Jam Kerja secara parsial berpengaruh signifikan terhadap pendapatan nelayan pemilik Payang di Kecamatan Koto Tangah kota Padang. 3) Pengalaman secara parsial berpengaruh signifikan terhadap pendapatan nelayan pemilik Payang di Kecamatan Koto Tangah kota Padang. 4) modal, jam kerja dan pengalaman secara simultan berpengaruh signifikan terhadap pendapatan nelayan pemilik Payang di Kecamatan Koto Tangah kota Padang. Berdasarkan hasil penelitian ini diperoleh variabel modal merupakan variabel paling dominan berkontribusi terhadap pendapatan nelayan yang diperolehnya dari aktivitas melaut.
\end{abstract}

Keywords: Income, Capital, Hours of Work, Experience and Fishermen

C2016 Prodi Pendidikan Ekonomi STKIP PGRI, Padang 


\section{PENDAHULUAN}

Indonesia adalah Negara maritim dengan wilayah laut yang sangat luas. Wilayah lautan yang luas ini dapat menimbulkan banyak kegiatan ekonomi penduduk dengan pemanfaatan sumberdaya laut, khususnya untuk masyarakat yang bermukim di wilayah pantai. Indonesia memiliki kawasan laut dan pantai yang bernilai produktif dan memegang peranan penting bagi pembangunan perekonomian.

Indonesia berada pada posisi yang strategis antar dua benua dan dua samudera. Posisi ini menyebabkan Indonesia memiliki sumberdaya laut yang bernilai produktif seperti potensi perikanan yang sangat besar, dimana perikanan merupakan salah satu subsektor pertanian yang menopang perekonomian Indonesia. Hal ini terlihat dari peran sektor perikanan terhadap pertumbuhan ekonomi mengalami peningkatan setiap tahun dimana pada tahun 2015 adalah sebesar 56,97\% (Sumber:BPS Kota Padang Dalam Angka Tahun2015).

Masyarakat yang berada di
kawasan pesisir memiliki mata
pencaharian utama sebagai nelayan.
Sektor perikanan memberikan kontribusi dalam peningkatan kesejahteraan nelayan. Dalam hal ini perikanansebagai salah satu SDA (Sumber Daya Alam) yang mempunyai peranan penting dan strategis dalam pembangunan perekonomian nasional terutama dalam meningkatkan perluasan kesempatan kerja di sektor perikanan tangkap.
Sumber daya perikanan secara potensial dapat dimanfaatkan untuk meningkatkan taraf hidup masyarakat nelayan,namun pada kenyataannya masih cukup banyak nelayan yang belum dapat meningkatkan hasil tangkapannya, sehingga tingkat pendapatan nelayan tidak meningkat.

Dalam hal ini terlihat nelayan memperoleh produksi ikan laut yang berbeda-beda antar sesama nelayan sesuai dengan jenis ikan yang dihasilkan maka harga ikan laut juga akan bervariasi tergantung jenis ikan laut. Menurut Fauzi (2010:102) dalam mengeksploitasi (menangkap ikan) di suatu perairan dibutuhkan berbagai sarana. Sarana tersebut merupakan faktor input yang disebut sebagai suatu effort atau upaya. Input tersebut seperti modal fisik (kapal dan alat tangkap), tenaga kerja yang dibutuhkan dalam untuk suatu aktivitas penangkapan dalam menghasilkan stok ikan atau produksi perikanan dan harga ikan berdasarkan satuan output atau produksi ikan.

Menurut Mankiw (2009:336) Dalam kegiatan produksi membutuhkan adanya faktor-faktor produksi seperti tanah, modal dan tenaga kerja. Dengan adanya faktor produksi tersebut maka dapat dilakukan kegiatan proses produksi. Produksi ikan laut yang dihasilkan oleh nelayan diduga dipengaruhi oleh modal, tenga kerja dan pengalaman.

Dengan adanya modal kerja maka usaha nelayan dalam melaut untuk menangkap ikan dan kemudian menghasilkan jumlah ikan 
tangkapannya. Makin besar modal kerja maka makin besar pula peluang hasil tangkapan yang diperoleh. Dalam hal ini dapat terlihat ketersediaan modal kerja yang dimiliki nelayan berupa asset atau modal yang dimiliki oleh nelayan pemilik seperti harga beli kapal dan modal dalam aktivitas sekali melaut (umpan, es balok, bahan bakar yang digunakan dan makanan/minuman pekerja).

Faktor jam kerja dikaji dalam penelitian ini karena produksi sangat dipengaruhi oleh jam kerja. Sebagaimana diketahui bahwa dalam teori faktor produksi jumlah output/produksi bergantung pada frekuensi kerja atau jam kerja. Berdasarkan kondisi tersebut maka penting untuk dikaji permasalahan terkait dengan jam kerja dalam melaut yang berdampak terhadap pendapatan nelayan.

Pengalaman melaut nelayan juga memberikan dampak pada hasil tangkapan nelayan. Faktor pengalaman, menurut Foster (2001:43)Hal yang menentukan berpengalaman tidaknya seorang dapat dilihat dari lama waktu atau masa kerja yang ditempuh seseorang sehingga dapat memahami tugas-tugas sebuah pekerjaaan dan telah melaksanakan pekerjaan tersebut dengan baik.

Rata-rata pengalaman nelayan dalam aktivitas melaut dengan motor tempel di atas 13 tahun. Pengalaman nelayan dalam melaksanakan aktivitas melaut akan memberikan dampak pada pencapaian hasil produksi ikan laut. Semakin bervariasi modal, tenaga kerja dan pengalaman nelayan dalam melaut akan berdampak terhadap jumlah produksi ikan laut tangkapan nelayan dengan motor tempel.

\section{METODE PENELITIAN}

Jenis penelitian ini adalah deskriptif assosiatif. Data yang digunakan dalam penelitian ini adalah data primerdengan menggunakan kuesioner terbuka. Populasi dalam penelitian ini adalah nelayan di kecamatan Koto Tangah Kota Padang dengan teknik pengambilan sampel adalah teknik purposive sampling sehingga jumlah sampel dalam penelitian ini adalah 111 orang nelayan pemilik payang.

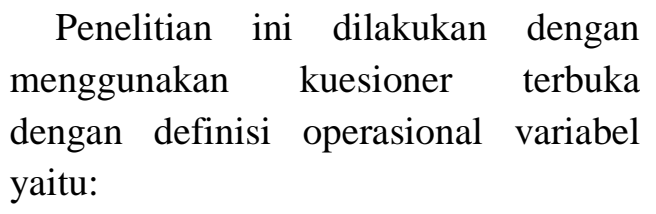

1. Pendapatan nelayan adalah nilai yang diterima dari nelayan dari hasil penjualan hasil tangkapan yang diukur dalam satuan rupiah.

2. Modal kerja pribadi adalah nilai yang dikeluarkan oleh nelayan dalam memperoleh hasil tangkapan yang terdiri dari : bahan bakar (solar), bahan pengawet ikan (es balok) dan bekal yang diukur dalam satuan rupiah.

3. Jam kerja adalah lamanya waktu nelayan melaut untuk mencari hasil tangkapan dari aktivitas melaut yang dihitung dalam satuan jam. 
4. Pengalaman adalah lamanya nelayan berprofesi sebagai nelayan perikanan laut yang diukur dalam satuan tahun.

Metode analisis yang digunakan dalam penelitian ini adalah Ordinary Least Square (OLS) denganmodel analisis Regresi Berganda(Multiple Regression) dengan tujuanuntuk mengetahui seberapa besar pengaruh variabel independen terhadap variabel dependen. Model regresi berganda pada penelitian ini adalah:

$$
\mathrm{Y}=\mathrm{C}+\beta 1 \mathrm{X} 1+\beta 2 \mathrm{X} 2+\beta 3 \mathrm{X} 3+\mathrm{e}
$$

Dengan melakukan elaborasi teori-teori diatas, maka dapat digambarkan kerangka berfikir seperti berikutini:

Keterangan:

$$
\begin{aligned}
& \mathrm{Y}=\text { Pendapatan Nelayan }(\mathrm{Rp}) \\
& \mathrm{C}=\text { Konstanta } \\
& \beta 1, \beta 2, \beta 3=\text { Koefisien regresi } \\
& \mathrm{X} 1=\text { Modal }(\mathrm{Rp}) \\
& \mathrm{X} 2=\text { Jam Kerja (jam) } \\
& \mathrm{X} 3=\text { Pengalaman (tahun) } \\
& \mathrm{e} \quad \text { Error (variabel bebas lain } \\
& \quad \text { diluar model regresi }
\end{aligned}
$$

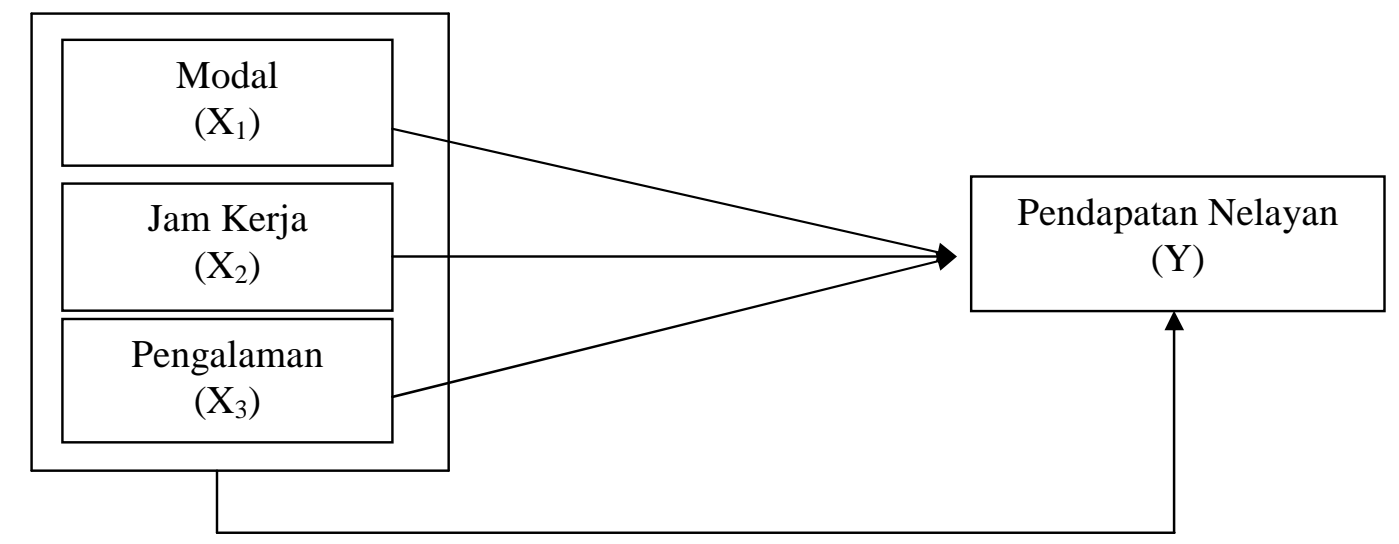

Gambar 1. Kerangka Konseptual

Berdasarkan kerangka konseptual diatas, maka dapat dikemukakan hipotesis terhadap masalah yang hendak dibahas melalui penelitian ini yaitu:

1. Pengaruh modal terhadap pendapatan nelayan pemilik
Pendapatan Nelayan

(Y)

payang di kecamatan Koto Tangah Kota Padang.

2. Pengaruh jam kerja terhadap pendapatan nelayan pemilik payang di kecamatan Koto Tangah Kota Padang.

3. Pengaruh pengalaman terhadap 
pendapatan nelayan pemilik payang di kecamatan Koto Tangah Kota Padang.

4. Pengaruh modal, jam kerja dan pengalaman terhadap pendapatan nelayan pemilik payang di kecamatan Koto Tangah Kota Padang.

\section{PEMBAHASAN}

\section{Karakteristik Responden}

Umur responden yang dimaksud pada penelitian ini adalah umur nelayan di Kecamatan Koto Tangah Kota Padangdengan sampel penelitian sebanyak 111 nelayanmenunjukan bahwa umur nelayan paling banyak adalah 35-39 tahun yaitu (29,0\%) dan paling sedikit adalah pada rentang umur 60-65 tahun $(0, \%)$ dengan ratarata umur nelayan yang melakukan aktivitas melaut adalah umur 43 tahun dengan umur terkecil 30 tahun dan umur terbesar 65 tahun.

\section{Analisis Deskriptif Variabel Pendapatan}

Pendapatan nelayan payang adalah hasil penerimaan dari aktivitas dalam satu kali melaut di Kecamatan Koto Tangah Kota Padangmenunjukkan bahwa pendapatan nelayan payang setiap satu kali melaut paling banyak adalah Rp.540.000-Rp.2.856.666 yaitu $(94,8 \%)$ responden dan paling sedikit adalah Rp.2.856.667Rp.5.173.333yaitu (5,2\%) responden dengan rata-rata pendapatan Rp.1.970.782 pendapatan tertinggi Rp.3.400.000 dan terendah Rp.540.000.

\section{Analisis Deskriptif Variabel Modal}

Modal terhadap pendapatan nelayan pemilik kapal di Kecamatan Koto Tangah Kota Padangmenunjukkan bahwa modal yang paling banyakadalah Rp.139.000Rp.2.059.125 yaitu 74,6\% responden dan paling sedikit adalah Rp.10.659.756Rp.12.579.881 yaitu $2,1 \%$ dan rata-rata modal Rp.3.780.000.

\section{Analisis Deskriptif Variabel Jam Kerja}

Jam kerja terhadap pendapatannelayan pemilik kapal di Kecamatan Koto Tangah Kota Padang menunjukkan jam kerja paling banyak adalah 10-29 jam yaitu sebanyak $79,8 \%$ responden dan paling sedikit adalah 110-129 jam dan 130-139 yaitu 0,5\% responden dan rata-rata jam kerja yaitu 33 jam dan jam kerja paling banyak adalah 168 jam dan paling sedikit adalah 10 jam.

\section{Analisis Deskriptif VariabelPengalaman}

Pengalaman kerja terhadap pendapatan nelayan pemilik kapal di Kecamatan Koto Tangah Kota Padang

menunjukkan bahwa pengalaman paling banyak adalah 17-20 tahun yaitu sebanyak $19,7 \%$ responden dan paling sedikit adalah 29-30 tahun yaitu $9,3 \%$ dan rata-rata pengalaman kerja nelayan yaitu 17 tahun.

\section{Hasil Estimasi Persamaan}

Dari estimasi yang dilakukan, didapat model persamaan pendapatan nelayan sebagai berikut:

$$
\begin{aligned}
& Y=5,728+2,420 X_{1}+0,013 X_{2}+0,002 \\
& X_{3}
\end{aligned}
$$

Dari model persamaan regresi berganda di atas dapat diketahui bahwa nilai konstanta sebesar 5,728yang berarti bahwa tanpa 
adanya pengaruh dari variabel modal, jarak tempuh, jam kerja dan pengalaman nelayan maka pendapatan nelayan barubernilai 5, 728 .

Hipotesis 1, terdapat pengaruh antara modal $\left(\mathrm{X}_{1}\right)$ terhadap pendapatan (Y) dengan nilai koefisien regresi modal sebesar 2,420 apabila modal meningkat sebesar satu persen maka pendapatan akan meningkat sebesar 2,420dalam setiap persennya dengan asumsi variabel lain tidak mengalami perubahan atau konstan dan nilai $t_{\text {hitung }}$ sebesar $15,67>t_{\text {tabel }}$ sebesar 1,98 sedangkan nilai signifikan $0,000<0,05$, berarti $\mathrm{H}_{\mathrm{a}}$ diterima dan $\mathrm{H}_{0}$ ditolak dengan demikian dapat dikatakan bahwa terdapat pengaruh antara modal terhadap pendapatan nelayan pemilik payang di Kecamatan Koto Tangah Kota Padang.

Hipotesis 2, terdapat pengaruh antara jam kerja $\left(\mathrm{X}_{2}\right)$ terhadap pendapatan (Y) dengan nilai koefisien regresi jam kerja sebesar 0,013. Hal ini berarti adanya pengaruh jam kerja terhadap pendapatan, apabila jam kerja meningkat sebesar satu persen maka pendapatan akan meningkat sebesar 0,013 dalam setiap persennya dengan asumsi variabel lain tidak mengalami perubahan atau konstan dan nilai $t_{\text {hitung }}$ sebesar $2,47>t_{\text {tabel }}$ sebesar 1,98 sedangkan nilai signifikan 0,015<0,05, berarti $\mathrm{H}_{\mathrm{a}}$ diterima dan $\mathrm{H}_{0}$ ditolak dengan demikian dapat dikatakan bahwa terdapat pengaruh antara jam kerja terhadap pendapatan nelayan pemilik payang di Kecamatan Koto Tangah Kota Padang.

Hipotesis 3, terdapat pengaruh antara pengalaman $\left(\mathrm{X}_{3}\right)$ terhadap pendapatan $(\mathrm{Y})$ dengan nilai koefisien regresi pengalaman kerja sebesar 0,002. Hal ini berarti adanya pengaruh pengalaman kerja terhadap pendapatan, apabila pengalaman meningkat sebesar satu persen maka pendapatan akan meningkat sebesar 0,002 dalam setiap persennya dengan asumsi variabel lain tidak mengalami perubahan atau konstan dan nilai $t_{\text {hitung }}$ sebesar 3,12 $>t_{\text {tabel }}$ sebesar 1,98 sedangkan nilai signifikan $0,0023<0,05$, berarti $\mathrm{H}_{\mathrm{a}}$ diterima dan $\mathrm{H}_{0}$ ditolak dengan demikian dapat dikatakan bahwa terdapat pengaruh antara pengalaman kerja terhadap pendapatan nelayan di Kecamatan Koto Tangah Kota Padang.

Berdasarkan nilai $R$ square sebesar 0,738274 yang artinya $73,83 \%$ perubahan pada variabel dependen (pendapatan) dapat dijelaskan oleh variabel independen (modal, jam kerja, dan pengalaman) sedangkan sisanya sebesar $26,17 \%$ dipengaruhi oleh variabel lain yang tidak termasuk kedalam penelitian ini.

$F_{\text {hitung }} 100,6081>F_{\text {tabel }} 2,68$ dan nilai signifikan $0,000<0,05$. Hal ini berarti $\mathrm{H}_{0}$ ditolak dan $\mathrm{H}_{\mathrm{a}}$ diterima, Dengan demikian dapat dikatakan bahwa modal, jam kerja, dan pengalaman kerja secara simultan berpengaruh terhadap pendapatan nelayan pemilik payang di Kecamatan Koto Tangah Kota Padang. 


\section{Tabel 1. Hasil Uji Persamaan Pendapatan Nelayan}

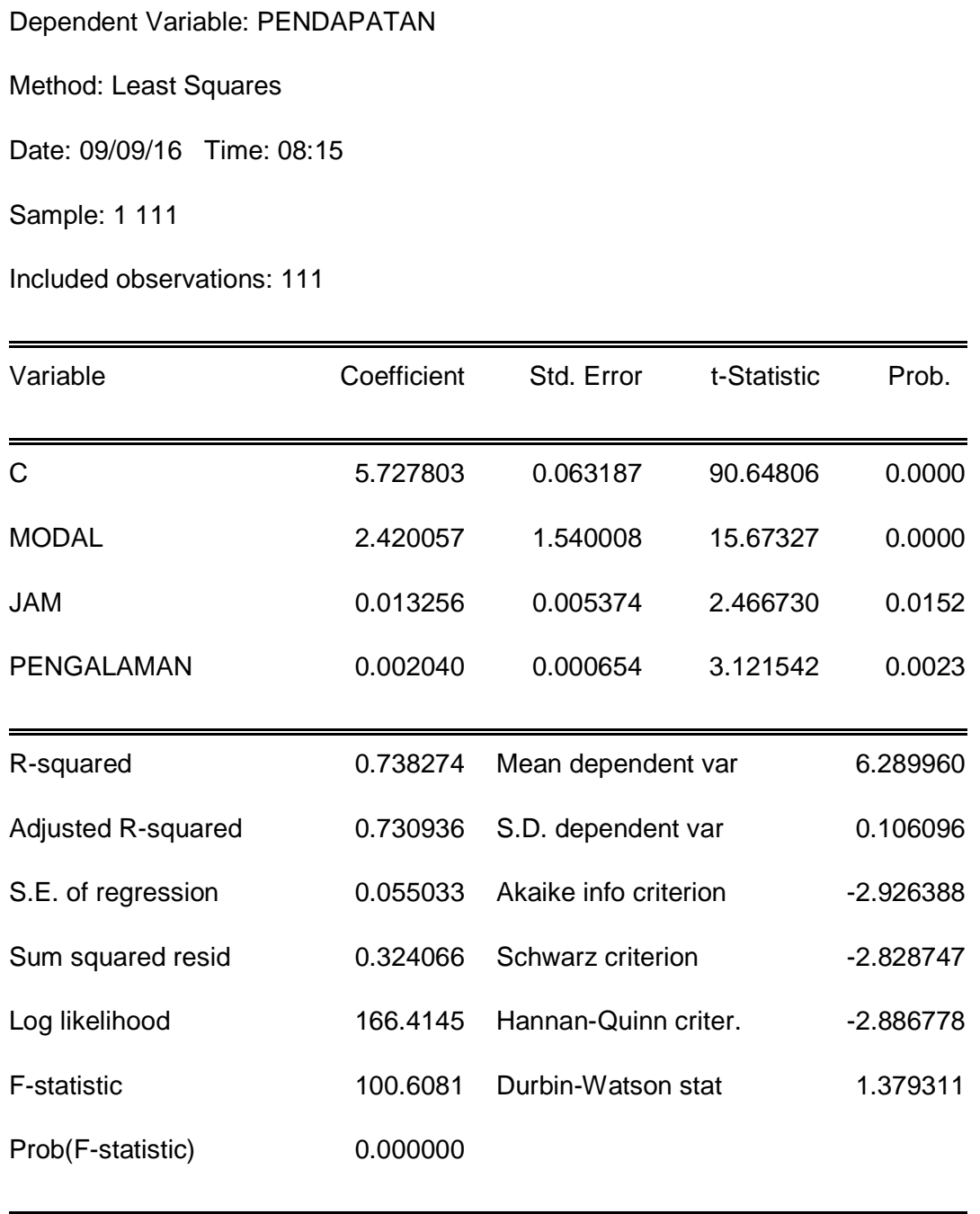

Sumber: hasil olahan data sekunder dengan eviews, $n=111$

\section{Pengaruh Modal Terhadap Pendapatan Nelayan Pemilik Kapal Payang di kecamatan Koto Tangah Kota Padang}

Berdasarkan hasil penelitian nelayan payang terdapat pengaruh signifikan antara modal $\left(\mathrm{X}_{1}\right)$ terhadap pendapatan $(\mathrm{Y})$ dengan nilai koefisien regresi modal sebesar 2,420.dan nilai $t_{\text {hitung }}$ sebesar 15,67> $t_{\text {tabel }}$ sebesar 1,98 sedangkan nilai signifikan
$0,000<0,05$.

Penelitian ini menemukan bahwa secara parsial modal mempengaruhi produksi ikan laut tangkapan nelayan secara positif. Artinya semakin banyak jumlah modal akan meningkatkan produksi ikan laut tangkapan nelayan pemilik motor tempel di Kota Padang. Artinya meningkatnya modal disebabkan oleh meningkatnya pendapatan nelayan sehingga nelayan mempunyai kemampuan yang tinggi untuk menambah 
persediaan bahan bakar dalam melaut, persediaan es balok, mengganti mesin rusak dan memperbaiki kapal sehingga layak untuk dibawa melaut serta memiliki alat tangkap yang lebih tinggi teknologinya sehingga nelayan tersebut dapat meningkatkan hasil produksi ikan laut tangkapan nelayan, yang pada gilirannya akan dapat meningkatkan pendapatan pemilik usaha nelayan tangkap dengan motor tempel di Kota Padang.

Temuan penelitian ini konsisten dengan teori Mankiw (2009:336) yang terkait hubungan antara modal dan produksi, dalam kegiatan produksi membutuhkan adanya faktor produksi salah satunya adalah modal. bila modal meningkat maka produksi juga meningkat. Hal ini menunjukkan kepada kita bahwa dalam peningkatan output harus didiringi dengan peningkatan input, salah satu input yang dibutuhkan dalam proses produksi merupakan modal. Dengan demikian temuan penelitian ini membuktikan bahwa peningkatan dari modal nelayan memberikan pengaruh positif dapat meningkatkan produksi ikan laut dan meningkatkan pendapatan nelayan.

Hasil penelitian ini sesuai dengan penelitian yang dilakukan oleh (Desi Astuti, 2015) variabel yang berpengaruh secara signifikan terhadap pendapatan nelayan di Kabupaten Langkat adalah modal kerja.

Hasil penelitian ini juga sejalan dengan penelitian yang dilakukan oleh
(Mariani, Aimon, \& Sentosa, 2014) Bentuk pengaruh modal kerja (X3) terhadap produksi ikan laut adalah positif artinya, semakin meningkat jumlah modal kerja maka produksi ikan laut nelayan juga akan meningkat sehingga dapat menambah pada nilai pendapatan yang diterima oleh nelayan.

Menurut (Silallahi \& Wahyu Maulid Diansyah, 2014) modal sangat berpengaruh terhadap pendapatan nelayan karena jika modal yang dikeluarkan sedikit maka pendapatan yang didapatkan sedikit juga, jika dengan modal yang besar untuk membeli alat tangkap yang bagus maka hasil tangkapan ikan meningkat dan pendapatan juga akan meningkat.

Pengaruh Pengaruh Jam Kerja Terhadap Pendapatan Nelayan Pemilik Kapal Payang Di Kecamatan Koto Tangah Kota Padang.

Berdasarkan hasil penelitian pada nelayan payang terdapat pengaruh signifikan antara jam kerja $\left(\mathrm{X}_{3}\right)$ terhadap pendapatan(Y) dengan nilai koefisien regresi jam kerja sebesar 0,013 dengannilai $t_{\text {hitung }}$ sebesar $2,47>t_{\text {tabel }}$ sebesar 1,98 sedangkan nilai signifikan $0,0152<0,05$.

Pada umumnya penangkapan ikan lepas pantai yang dilakukan dalam waktu yang lebih lama dan lebih jauh dari daerah sasaran tangkapan ikan mempunyai lebih banyak kemungkinan memperoleh hasil tangkapan (produksi) yang lebih banyak dan tentu memberikan pendapatan yang lebih besar dibandingkan dengan penangkapan ikan dekat pantai.

Pengaruh Pengalaman Kerja Terhadap Pendapatan Nelayan Pemilik Kapal 


\section{Payang Di Kecamatan Koto Tangah Kota Padang}

Berdasarkan hasil penelitian pada nelayan payang terdapat pengaruh signifikan antara pengalaman kerja $\left(\mathrm{X}_{4}\right)$ terhadap pendapatan $(\mathrm{Y})$ dengan nilai koefisien regresi pengalaman kerja sebesar 0,002 dengan nilai $t_{\text {hitung }}$ sebesar 3,12 $>t_{\text {tabel }}$ sebesar 1,98 sedangkan nilai signifikan $0,0023<0,05$.

Hasil penelitian ini sesuai dengan penelitian yang di lakukan oleh (Agunggunanto, n.d.) Pengalaman sebagai nelayan secara langsung maupun tidak, memberi pengaruh kepada hasil penangkapan ikan. Semakin lama seseorang mempunyai pengalaman sebagai nelayan, semakin besar hasil dari penangkapan ikan dan pendapatan yang diperoleh.

Menurut Mankiw, (2003:553)

Modal manusia yang diperoleh melalui pengalaman kerja turut menentukan jumlah produksi barang dan jasa. Semakin lama pengalaman kerja seseorang maka semakin tinggi output yang dihasilkan dan semakin rendah pengalaman seseorang maka semakin rendah output yang dihasilkannya.

Sejalan dengan pendapat
Jhingan, (2003:416)
meningkatkan output dari sisi
kuantitas dan kualitas membutuhkan
pengalaman tenaga pekerja karena
pengalaman bagian dari pembentukan
modal manusia. Jika modal manusia
tidak memadai jumlahnya, maka
modal fisik tidak akan dapat

dimanfaatkan secara produktif akibatnya mesin menjadi cepat rusak dan tidak terpakai, bahan-bahan dan komponen terbuang serta kualitas dan kuantitas produk turun.

Dengan demikian dapat diketahui apabila seseorang sudah lama berprofesi sebagai nelayan baik pemilik maupun anak buah kapal, maka nelayan memiliki kemampuan yang lebih dalam mengidentifikasi kondisi laut, memahami cara perawatan dan perbaikan kapal dari kerusakan serta memiliki strategi untuk menghasilkan ikan yang baik secara kualitas dan kuantitas maka hal ini akan memberikan peningkatan dalam pendapatan nelayan tersebut.

Pengaruh Modal, Jam Kerja dan Pengalaman Kerja Terhadap Pendapatan Nelayan Pemilik Kapal Payang Di Kecamatan Koto Tangah Kota Padang.

Berdasarkan hasil penelitian pada nelayan keseluruhan $F_{\text {hitung }} 100,6081>F_{\text {tabel }}$ 2,68 dan nilai signifikan $0,000<0,05$, berarti $\mathrm{H}_{0}$ ditolak dan $\mathrm{H}_{\mathrm{a}}$ diterima, dengan demikian dapat dikatakan bahwa modal, jam kerja, dan pengalaman kerja secara simultan berpengaruh terhadap pendapatan nelayan pemilik kapal di Kecamatan Koto Tangah Kota Padang, dimana pendapatan nelayan payang setiap satu kali melaut paling banyak adalah Rp.540.000-Rp.2.856.666 yaitu $(94,8 \%)$ responden dan paling sedikit adalah Rp.2.856.667-Rp.5.173.333 yaitu (5,2\%) responden dengan rata-rata pendapatan Rp.1.97-.782 pendapatan tertinggi Rp.3.400.000 dan terendah Rp.540.000.

Berdasarkan nilai $R$ square sebesar 0,7383 yang artinya $72,83 \%$ perubahan pada variabel dependen (pendapatan) dapat 
dipengaruhi variabel independen (modal, jam kerja, dan pengalaman kerja) sedangkan sisanya sebesar $26,17 \%$ dipengaruhi oleh variabel lain yang tidak termasuk kedalam penelitian ini.

Temuan penelitian ini didukung oleh pendapat Joesron (2012:87) yang menyatakan bahwa pendapatan ditentukan oleh kemampuan faktor-faktor produksi dalam menghasilkan output. Semakin besar kemampuan faktor produksi menghasilkan ouput maka semakin besar pendapatan yang diciptakan. Hasil penelitian ini konsisten oleh pendapat Nicholson (2002:229) penjualan produksi/ouput yang lebih tinggi mengakibatkan penerimaan yang lebih besar. Jika nelayan dapat meningkatkan hasil produksi ikan laut tangkapannya maka akan dapat terjadi peningkatan pendapatannya.

Pendapatan merupakan suatu hal yang sangat penting dalam menentukan laba atau rugi dari suatu usaha, laba atau rugi tersebut diperoleh dengan melakukan perbandingan antara pendapatan dengan beban atau biaya yang dikeluarkan atas pendapatan tersebut. Pendapatan dapat digunakan sebagai ukuran dalam menilai keberhasilan suatu usaha dan juga faktor yang menentukan dalam kelangsungan suatu usaha. Pendapatan dapat diartikan sebagai jumlah uang yang diterima oleh seseorang atau badan usaha selama jangka waktu tertentu.

\section{PENUTUP}

\section{Kesimpulan}

Berdasarkan hasil analisis data yang telah dilakukan dapat disimpulkan sebagai berikut:

1. Pada nelayan payang di Kecamatan Koto Tangah terdapat pengaruh antara modal $\left(\mathrm{X}_{1}\right)$ terhadap pendapatan $(\mathrm{Y})$ dengan nilai koefisien regresi modal sebesar 2,42.dan nilai $t_{\text {hitung }}$ sebesar $15,67>t_{\text {tabel }}$ sebesar 1,98 sedangkan nilai signifikan $0,000<0,05$.

2. Pada nelayan payang di Kecamatan Koto Tangah terdapat pengaruh signifikan antara jam kerja $\left(\mathrm{X}_{3}\right)$ terhadap pendapatan( $(\mathrm{Y})$ dengan nilai koefisien regresi jam kerja sebesar 0,013 dengannilai $t_{\text {hitung }}$ sebesar 2,47> $t_{\text {tabel }}$ sebesar 1,98 sedangkan nilai signifikan $0,0152<0,05$.

3. Pada nelayan payang terdapat pengaruh signifikan antara pengalaman kerja $\left(\mathrm{X}_{4}\right)$ terhadap pendapatan (Y) dengan nilai koefisien regresi pengalaman kerja sebesar 0,002 dengan nilai $t_{\text {hitung }}$ sebesar $3,122>t_{\text {tabel }}$ sebesar 1,98 sedangkan nilai signifikan $0,0023<0,05$.

4. Pada nelayan di Kecamatan Koto Tangah secara simultan $F_{\text {hitung }} 100,6081$ $>F_{\text {tabel }} 2,68$ dan nilai signifikan 0,000<0,05berarti $\mathrm{H}_{0}$ ditolak dan $\mathrm{H}_{\mathrm{a}}$ diterima, dengan demikian dapat dikatakan bahwa modal, jam kerja, dan pengalaman kerja secara simultan berpengaruh terhadap pendapatan nelayan pemilik kapal Payang di Kecamatan Koto Tangah Kota Padang. 
Saran

Berdasarkan hasil dari penelitian, Penulis mengemukakan saran yang diharapkan dapat bermanfaat dalam meningkatkan pendapatan yang ditunjukan kepada nelayan.

1. Dalam upaya meningkatkan produksi perikanan tangkap nelayan dengan payang diharapkan kepada pemerintah Dinas Kelautan dan Perikanan Kota Padang untuk lebih memperhatikan kebutuhan modal kerjan nelayan dalam melaut sehingga nelayan dapat melakukan aktivitas melaut dengan optimal seperti pemberian bantuan mesihendaknya diberikan kepada nelayan yang kondisi mesin kapalnya sangat memprihatinkan dan membahayakan keselamatan jiwa nelayan tersebut dalam melakukan aktivitas melaut.

2. Upaya yang harus dilakukan pemerintah Kota Padang, hendaknya disetiap kecamatan yang berada di wilayah pesisir panatai didirikan pertamina kecil atau PETAMINI untuk memudahkan nelayan mendapatkn bahan bakar bersubsidi, sehingga nelayan sangat terbantu dalam memperoleh bahan bakar untuk melaut.

3. Nelayan di Kota Padang khususnya nelayan di kecamatan Koto Tangah mengharapkan pemerintah untuk mendirikan koperasi bagi nelayan untuk memberikan kemudahan bagi nelayan dalam mendapatkan modal untuk melaut dan menutupi biaya kebutuhan hidup jika nelayan tidak memperoleh hasil tangkapan yang optimal.

\section{DAFTAR PUSTAKA}

10.22202/economica.2016.v5.i1.891

Agunggunanto, E. Y. (n.d.). Analisis Kemiskinan dan Pendapatan Keluarga Nelayan Kasus di Kecamatan Wedung Kabupaten Demak Jawa Tengah. Dinamika Ekonomi Pembangunan, 1(1), 50- 58.

Arikunto, Suharsimi. (2009). Manajemen Penelitian. Jakarta : Rineka Cipta.

Desi Astuti, M. (2015). Analisis Faktorfaktor Yang Mempengaruhi Pendapatan Nelayan di Kabupaten Langkat. Jurnal Ilmiah Integritas, 1(4), 110-125.

Jhingan.M.L, (2003). Ekonomi Pembangunan dan Perencanaan., Jakarta: Rajagrafindo Persada.

Joesron, Tati S dan Fathorrozi. (2012). Teori Ekonomi Mikro. Jakarta: Salemba Empat.

Kusnadi. (2003). Akar Kemiskinan Nelayan. Yogyakarta : LKIS.

Malhotra K. Naresh. (2003). Marketing Research An Applied Orientation, second edition, Prentice Hall International Inc, New Jersey.

Mankiw, Gregory, N. (2003). Pengantar Ekonomi. Jilid 1. Ed. 3. Jakarta: Erlangga

Mariani, N., Aimon, H., \& Sentosa, S. U. (2014). Analisis Produksi dan Efisiensi Ikan Laut Nelayan Bagan Mesin di Koto XI Tarusan Kabupaten Pesisir Selatan. Jurnal Kajian Ekonomi, III(5).

Silallahi, A. D., \& Wahyu Maulid Diansyah, S. . (2014). Analisis Faktor-Faktor Yang Mempengaruhi Pendapatan Nelayan. Jurnal Kultura, 15(1), 44144421. 